\title{
Exile and Diaspora. Jewish Concepts of Dispersion
}

\author{
Régine Azria
}

\begin{abstract}
The Jewish experience of Diaspora can be seen as a condensation of the diasporic condition more universally because of the breadth of its dispersion over space and time and the changing circumstances which compelled the Jews to permanently adjust their frames of living and thinking down to the present. The present paper intends to illustrate this paradigmatic (albeit atypical) imprint of Diaspora, in processes subject to dynamic change, using two examples: (1) the place of the exile/return topic in religious and modern representations, moving from a center/periphery paradigm to one of circulation and mobility; (2) the confrontation between the Jewish traditional lexicon of Diaspora, which retained a traditional diasporic geography (Ashkenaz, Sefarad, Mizrah), dissociated from its territorial substratum, and real geography.
\end{abstract}

Keywords: community; Diaspora; identity; Israel; Judaism; representations

\section{The Jewish Diaspora: A Paradigmatic Though Atypical Case-Study}

Diasporas spread all over the world. This demographic phenomenon, though largely uneven in its occurrence and scope, raises questions among political and social scientists. Wherever their place of origin, men and women who are swept along in these large spatial redistributions are destined to live as migrants, no matter whether they are willing to assimilate, to share the way of life and speak the language of the surrounding people, or whether they prefer to live according to their own cultural and/or religious agenda. The phenomenon is not new but its scope seems to be unprecedented. This process affects the very texture of our societies and weakens their foundation of beliefs and certitudes (Azria 2002; Shain 2007).

The present paper looks at one such Diaspora, perhaps its classic instantiation: the Jewish Diaspora, which is situated squarely within this global context. One of the challenging issues of this essay is to determine the possible extent to which the Jewish example can serve as a paradigmatic case. Can it assist us to understand other diasporic situations, since the particular Jewish experience of Diaspora can be seen as a condensation of the diasporic condition at large, its historical epitome and prime exemplar. The breadth of its dispersion over space and time, the changing historical and political circumstances which compelled the Jews to permanently adjust their frames of living and thinking to their condition as a minority, imbue the Jewish experience of Diaspora with a structural and paradigmatic dimension, however atypical. As a paradigm of transterritorial, transnational existence, the Jewish Diaspora can serve as a lens through which to view other Diasporas, each very different: the Roma/Gypsy Diaspora, part of the broader Indian 
Diaspora; the Chinese Diaspora; the myriad Diasporas today and in the past driven by economic factors behind migration.

Except for the Greeks, the Jews represent the first acknowledged example of prolonged existential Diaspora in history. They appear to be the sole group systematically associated with the notion of Diaspora. ${ }^{1}$ This although unlike most diasporic groups which could share their identity and fate with a "center," i.e. a metropole, the Jewish Diaspora was not a limited nor a marginal phenomenon, involving only a segment of the Jewish population; neither was it a temporary phenomenon, a short-term event in Jewish history. It was a global and lasting historical phenomenon. Global, because the Jewish world as a whole was involved with it, and it was lasting: it first appeared in ancient times and still is a reality today. Therefore Diaspora should be considered an essential constituent of Judaism: it composes the frame within which the Jews invented Judaism and within which Judaism later found a chance to experience the concrete world. While exhausting its many levels of meaning - social, cultural, theological, religious, ideological, political - Diaspora was not just an external condition of Jewish life. In my view, Diaspora is a major structuring dimension of Judaism. Or phrased a different way: Judaism is a product of Diaspora. In this respect, the Jewish Diaspora is unique. As far as is known, no other diasporic group ever united all these features within their notion of Diaspora. Consequently, if the Jewish Diaspora appears atypical owing to its uncommon features, it at the same time appears paradigmatic due to the abundance of essential diasporic features.

Yet should the Jewish Diaspora simply be taken for granted? Was there a priori evidence of a diasporic fate for Jews? Were they forced to leave the land they had conquered after their tribes of origin had finally joined their forces to form one nation gathered around its king, its Law, and its Temple? The fact is that one of the main concerns for the Jews during the following two thousand years was to perceive, construct and represent themselves as a dispersed people sent into exile. From that time on, the idea of return became a shared expectation strong enough to serve as a religious and political binder. One may assume that other groups in similar situations could lose their specific national features in the long run and could have disappeared through assimilation. Therefore, during their sojourn over centuries in the gentile world, Jews were determined to protect their cultural and religious particularism. They were eager to cultivate relationships with the local Jewish environment as well as to weave long-distance networks with their fellow Jews beyond the borders. Under different circumstances, on different scales and using different means, other groups and communities did the same, but differently, as for instance, Christians via evangelization, missions and military conquests; or Muslims via establishing the dar-al-islam (the house of Islam). Both groups succeeded in becoming the devotees of transnational worldwide organizations. But the conditions the Jews had to face were quite different: contrasting with Christians and Muslims, they formed separate groups everywhere, isolated within an alien if not hostile world; they claimed to observe strict endogamy and were not fired with enthusiasm for proselytism. In order to survive as Jews and to preserve Judaism, they had to invent new inner strategies aimed at their own fellow Jews rather than at the outside world. Their leaders had to keep them conscious of their belonging to a large but scattered family, each of its members, segments or

1 The presence of Jews beyond the borders of Ancient Israel is attested very early, long before the Christian era. 
communities having to be kept aware it was part of a larger network system, connected to others via the Law and a common ancestral language (Hebrew), via a common past and shared expectations, via diverse exchanges and solidarity links (family, economic, religious). Less rational and understandable though is the persistence of the link with the lost place, an imaginary elsewhere, which ages ago, had been the land of their remote Hebrew ancestors. How can one explain that Jews living today in Sydney, Moscow, Teheran, New York or Paris still view themselves as exiled from Zion, whereas in the time spans in between so many concrete and painful exiles punctuated their tormented history? They are indeed a group repeatedly pushed into exile. That would suggest that Diaspora is not a mere factual historical phenomenon, but also and perhaps primarily a subjective construct, a self-representation as well as a representation of the other, the core of a nationalethnoreligious imaginary.

At this point, an ultimate argument for the persistence of Jewish Diaspora should be added to those already mentioned: Jews not only incorporated the diasporic dimension of their history into their collective memory, they also included it into their religious representations and gave it a theological dimension. Far from considering the Diaspora/exile event as fortuitous and marginal, Jewish scholars tended to interpret it as part of a divine plan within which it was to play a major role with regard to the messianic process of redemption. However, referring to Messianism and redemption should not give rise to a misunderstanding. It does not suggest that the religious sages were willing to postpone redemption and the end of exile somewhere beyond the frontiers of human history. Quite the contrary, they did insist on the fact that its drama is being performed here below, in this world, that it closely follows the very folds and contortions of history, and merges into its breakings and upheavals, as the messianic turmoil generated by Sabbatai Tsvi in the 17th century illustrates (Scholem 1973). In contrast to this particular dramatic event, the Rabbis also stressed that although the end of history is supposed to be known, its paths and the precise date of its coming are not. The tortuous course of history, full of pitfalls, unfolds according to a process the Scriptures compare to the pangs of childbirth and delivery: ${ }^{2}$ the return of the Jews to their ancestral land is the expected end they are hoping for since ages, but like the childbirth, this expectation is experienced with awe and tremor. ${ }^{3}$ Neither modernity nor the process of rationalization and secularization, even political Zionism and the implementation of its project of return for the Jews, ever seriously damaged this eschatological theological aspect. The religious argumentation regarding exile and Diaspora still keeps its relevance today, except that it can no longer lay claim to a monopoly and has gained ground on the political field. The present context of globalization and of unprecedented technological achievements in communication means abolishing the very notion of distance with regard to space and time. However, rather than to examine Diasporas as they disappear and undergo recomposition in their concrete forms and modes of self-representation, I intend to show that over against the center/periphery and exile/return paradigms, still relevant in popular conception and representation, a circulation/mobility paradigm is juxtaposed. Its effects are palpable, in the Jewish case and among other things, in the shift of the words and concepts used to de-

2 Isaiah 37, 3; 51, 6; 66, 8; Hosea 13, 13.

3 Jewish mystical texts compare the times prior to the coming of the Messiah to the labor pains of childbirth. 
scribe and frame the diasporic Jewry, from the traditional lexicon to a universalist lexicon.

\section{The Diaspora Paradigm in Jewish Traditional Representations and the place of the State of Israel ${ }^{4}$}

Rabbis and scholars have assigned a two-fold connotation to Diaspora: negative and positive. Negative as a synonym for exile and divine punishment; ${ }^{5}$ positive as the mission assigned to Jews. In both cases, the notion of Diaspora is heavily infused with Messianism. As the bearer of an expectation, it removes Jews from their wretched existential condition, pressing them to overcome their narrow perspective, while setting a double goal: 1) the return to Zion, which means putting an end to exile; 2) to be "a Light unto the nations" (Isaiah 49,6), this mission being viewed as the ultimate destination of the Jewish dispersion. Judaism was shaped and molded by its artisans, i.e. its Rabbinical and secular elite, to fit history from this permanent tension between the singular fate of a particular people and the universal call proper to biblical monotheism.

Ideally speaking, the Diaspora paradigm accounts for this situation of a group, physically rent across vast spaces and scattered, whose sacralized memory of its mythical past and the idealized vision of its messianic future point to the same and unique 'elsewhere' in space and time; a group whose awareness to be a people is nourished with the thought of this elsewhere, this thought being itself nourished with the narrative of its origin, as written in Scripture, commented by tradition, codified in the ritual, theatrically performed in liturgy. In other words, a people in the eyes of which the very thought of a 'elsewhere' constitutes the memory and the horizon, the ferment and the reason for hope and perseverance.

Among the questions raised by this theological construct, the concern with the focal point and center of Diaspora requires particular attention, at least on a political level. According to conventional political categories, the center usually refers to the representative body/bodies of a legitimate power or authority: monarchy, state, nation, territory, church, party. Therefore, since the creation of a Jewish State, the Jewish center, concretized in the State of Israel, was territorialized and politicized.

Israel is a complex figure. In its traditional approach: rather than as a center, it is viewed as a totality. The polysemy of the word - referring to the people (am yisrael), the Law (torat yisrael), the land (eretz yisrael) - bears witness to this multiplicity of meanings. Yet it is evident that this broad semantic spectrum, which assigns Israel a plurality of levels of meaning - human, religious, normative, ethic, geopolitical - largely goes beyond the notion of the existing State confined within borders, whatever their extension.

In addition, far from being an affirmation or the expression of something to be taken for granted, the invocation of the central character of Israel remains an open question, an invitation to ask what the center means for Jews, past and present. What does a center actually mean to a people, for which the historical experience has consisted in recurrent de-centerings, in the multiplication of places and sources of power and authority? What

4 This section is based in part on a previous paper, see Azria 1999.

5 Christian defenders of the theology of substitution consider exile as God's will, as the demonstration of the lapse of the Jews and the victory of the Church. See Simon 1948. 
sort of a place - place taken as concrete spot and as metaphor - is Israel supposed to be the center of? Is Israel a religious, a historical, a political, or a territorial center? One should not forget that since Sinai, despite (or owing to) their numerous migrations and the polycentrism resulting from the fragmentation of Jewish Diaspora, the idea of an exclusive center was always crucial: embodied as book, the Torah, and the Law. No doubt that Jews owe their historical survival as a collective entity to this atypical way of imagining a center in their own national imaginary.

Yet, to contemporary Jews and Gentiles, "Israel" refers primarily to the State. Owing to the historical circumstances of its birth in the aftermath of the judeocide, this State holds a special place in their consciousness. Due to the abiding legacy of a religious tradition, the restorationist dimension of a "return to Zion" was never totally abandoned in spite of its political reinterpretation. Among other things, the choice of Hebrew as the official language demonstrates it: the categories of thinking used in everyday life and the modern recycling of old words belonging to the traditional religious lexicon with the polysemy of the word "Israel," joined its mythical toponymy together with its legendary topography. As for the rituals, the liturgy, the mystic tradition, they substantially contributed to spiritualizing and sacralizing the figure of Israel, as well as the longing for "next year in Jerusalem" repeated by Jews since the Babylonian exile. In their dynamic aggregate, each of these elements contributed to keeping the map, image and idea of a restored Israel alive, in the absence of a real present one.

However, these contemporary and traditional motives are inadequate to readily identify the State of Israel with the meaning of centrality in Jewish Diaspora tradition. In Jewish diasporic discourse, there is no necessity and ineluctability of a Jewish restoration specifically on the territory of the ancient biblical kingdom.

The question of the center has been much debated in Jewish tradition and it seems that Jewish history is still concerned with this problematic question. As a matter of fact, a non-dogmatic, non-ideological approach to this complex would show the absence of a center, the permanent and recurrent interrogation of whether it was necessary to be realized. De-centering/decentralization and transterritoriality would better describe the contours of Jewish historical experience, which can be readily read and interpreted as a series of de-centerings. Actually, Israel is more frequently presented as a goal to be reached, an ideal to be fulfilled than as a real and concrete territorial, political or religious entity. If Israel is embodied in any of these modalities of reality, soon it fails: neither the Kingdom nor the Temple nor the Land were able to prevail in the face of reality and history. We can thus ask whether Israel is not doomed to remain the repeatedly promised and desired land. In that event, Israel would be the expected reward at the end of history in a millennial account, once the Promise is accomplished and Jews have fulfilled their mission in conformity with the Law. In other words, Israel would be the opposite of a hic et nunc reality. Israel would prove equal to what it represents only in so far as it remains a yearning after something. Israel would be doomed to remain a utopia. Rather than a center, Israel would be a horizon to reach out for.

Given the constraints of their human existence, Jews had difficulties in their efforts to meet their expectations. Nevertheless, they may answer the call, like Abraham, the son of an idolatrous father, born and raised outside eretz yisrael, in exile before time, in a spatial and spiritual exile, whose life was totally devoted to the pursuit of the center. That was a spiritual center when looking for and meeting God and his Law, torat yisrael, but also a territorial center when searching to enter the Promised Land, eretz yisrael, and became a national center when Abraham was chosen as the father of a holy nation, am yisrael (Gen. XII, 1-3). Abraham, the mythical patriarch of Israel, comes from the matrix of exile. It 
suggests that the center makes sense only when related to some other elusive "elsewhere" - which makes this center all the more desirable because, situated as it is on a distant horizon, it is not within reach. One could reiterate the demonstration and apply it to the whole people, the collective consciousness of which was forged in the Egyptian exile before it became self-aware thanks to its wandering through the desert. That people's self-consciousness was to be strengthened later on, in the subsequent dispersions from Babylonia to Alexandria, Djerba, Warsaw, Berlin.

In so far as it mingles with the notion of a center holding the exclusive control of legitimacy, the center, as a concrete entity, turned out to be eminently fluid and unsteady, even unsustainable over the course of Jewish history. Supported as a principle, it was contested and abused in reality. The political center embodied in the Hebrew Kingdom split up soon after it was established, through the schism between Judah and Israel. Already during the Talmudic era, the religious center was unable to resist the pressure of the competition between Babylonia and Jerusalem. As for the territorial center in Palestine, it was unable to resist the centrifugal forces of history with the dispersion. One could multiply the examples. Actually, the present global push toward diasporization should probably bring us to question anew the relevance of the "center paradigm" and suggest the "circulation and mobility paradigm" as its substitute, applicable to many peoples and vast communities of migrants seeking a more viable life.

\section{The Words of Diaspora: Exilic Lexicon and Real Geography}

Neither the existence of the State of Israel nor the de-dramatization (i.e. comparative 'normalization') of the Jewish condition outside of Israel succeeded in eroding the structuring power of the diasporic imprint. It remains quite deep and pronounced in Judaism down to the present. ${ }^{6}$ Since this imprint is particularly palpable in the language, its durability and effectiveness can be measured in different ways, including paying attention to discourse. If one agrees that the words we use are not neutral, that they are meant to give a shape to and express our thoughts, it is evident that the words we choose in order to describe, identify or name facts and things contribute to the building of reality as well as to its representation, to the representation we wish to emphasize or share with others. The "Temple Mount" (har ha-bait) or the "Esplanade of the Mosques" (haram esh-Sharif) are two very different designations for the same space and structure. That is also true with the lexicon of Jewish dispersion. The Hebrew words used for the Jewish narrative about its Diaspora, frame and outline a diasporic geography totally congruent with the traditional view of the Jewish collective fate, though dissociated and far removed from its territorial substratum. This Hebrew lexical geography of exile, evolved over millennia, became obvious and natural for Jews and a triple-branched structure: Ashkenaz, Sefarad, Mizrah. The word Diaspora itself is an incorrect rendering in Greek of the Hebrew gola/galut, the true meaning of which is exile rather than dispersion.

Considering this geography and the discourse that constructs and shapes it is illuminating, both for what it reveals and what it conceals. It is an integral part of Jewish history and of Jewish self-representation: while drawing on the map of the barriers, bifurca-

6 This de-dramatization can be attributed in part to the fact that since decolonization and the end of Soviet Union, most Jews live under liberal and democratic regimes. 
tions and divisions within the Jewish world, it names the concrete entities. By doing so, it defines the cultural shapes of Jewish identities and highlights Judaism's inner diversity. Despite later wanderings that blurred the original territorial arrangement, this discourse and its lexicon have endured over centuries and borders.

This Jewish toponymy within the notion of Diaspora, including its lacunae and approximations, is very instructive. For instance, it forgets quite a few diasporic areas: Ethiopia, Cochin, Kaifeng, the Caucasian Mountains, and others. These blanks are neither accidental nor intended to consciously exclude. They are simply the price to be paid by the concerned populations for their demographic insignificance, for their remoteness and insulation from the centers of Jewish life, for their more peripheralized and barely transmitted cultural capital. Such a situation, replete with marginality, was to cut short any claim by these diasporic enclaves to play a significant role beyond the limits of their local communities and environment. Being labeled neither Ashkenaz, nor Sefarad or Oriental, having no available resources enabling them to form and be considered in generic categories of their own, these diasporic places remained the forgotten territories of Jewish history for centuries. Some, like the Caucasian Mountains, were simply annexed to one of the previously mentioned categories. ${ }^{7}$

Yet the Ashkenaz /Sefarad /Oriental categories prevailed. Their identity was shaped in terms of two differing dimensions, two logics: territorial and cultural. In accordance with territory and with areas characterized by religion and language, the latter two would reinforce the former: the cultural matrix was the element supposed to cement the cohesion and durability of group identity should the territorial matrix fail.

Ashkenazic Jewry arose in Europe in the space including northeastern France, Germany (Ashkenaz 'proper') and Lotharingia long before the Jews had migrated eastward, and then much later in the late $19^{\text {th }}$ century to the United Kingdom and across the Atlantic. Ashkenazic Jewry owes its durable cultural particularism to Yiddish, the Jewish language Jews from Ashkenaz proper (the German-speaking core of Central Europe) elaborated and carried eastward in their subsequent moves (and then to the New World). Yiddish was to form the tool and cement of their culture. Sefarad Jewry, born in the Iberian peninsula, experienced a similar process. After their expulsion from Spain in 1492 and Portugal in 1498, Sefardi Jews met the identity challenge raised by their geographical dispersion thanks to the intellectual, literary and spiritual tradition they had cultivated on the soil of Sefarad, thanks to the shared Judeo-Spanish language they carried in their cultural luggage as they relocated to other host countries.

As for Oriental Jews, the presumed but distant heirs of ancient Jewry, their origins go back to the exile that followed the destruction of the First Temple. Scriptures relate that after their deportation to Babylon in 586 B.C., only some of the exiled Jews took up the invitation of Cyrus, the Persian ruler, to move back to their country. Most of them chose to stay. In doing so they actually substituted an expatriate status for their exiled identity. Babylonia (present-day Iraq) became the major Jewish diasporic center in the process. Later on, the Hellenized Jews of Alexandria and other Jews followed their example, settling along the Oriental and African coasts of the Mediterranean sea. Besides their religious particularism, their major unifying features were the Arabic language - and its Jew-

7 The Central Bureau of Statistics in Israel has included Jews in Central Asia and the Caucasus in the category edot ha-mizrah (oriental communities). 
ish versions - and their immersion in societies, which had converted to Islam. The Oriental haven maintained its intellectual and religious influence over the Jewish world for some 1,500 years (486 B.C. - 1099 A.C.) until its decline. The Hebrew term - edot ha mizrah ("Oriental communities") - may sound somehow amazing if one realizes that the Orient here covers an area that stretches from eastern Iran (Mashrek/Orient) to the Atlantic coast Morocco (Maghreb/Western), i.e. it covers the Mediterranean Basin from West to East and reaches far beyond its Asiatic confines, extending to the Caucuses. This term, not free from a certain condescension, sheds light on the way Western Jews used to consider and represent their other self, the "Oriental Jew.",

As much as the extension of Ashkenaz and the splitting up of Sefarad, the spatial expansion of this diasporic Orient blurred the relevance of the territorial characteristics. Whereas in the 8th century, the division of Europe in two major geopolitical blocs (Spain and the Roman-German Empire) framed two distinct Jewish civilizational areas - Ashkenaz and Sefarad - leaving the exclusiveness of Maghreb and Mashrek to Oriental Jewries, further political disorders led to a new deal and to the redistribution of labels. Thus, after the Jews of Spain banished by the Inquisition had crossed the Mediterranean and settled in North Africa, Jewish indigenous populations were progressively absorbed by their Sefardi co-religionists so much so that the Sefarad label changed. It was no longer solely the name used for the Jews from Spain, but referred to the totality of the Jews established in Islamic countries. Despite the large migrations that occurred later on, two geocultural entities thus remained in modern minds and representations regardless of their changing outlines: an Ashkenazic Jewry identified with the Christian West (Europe and the Americas); a Sefardi Jewry identified with the Arabic-Islamic world (Maghreb \& Mashrek), and the original Sefardi Jews of the Mediterranean (Italy and the Balkans) in between.

Historical distance permits the historian to question these distortions of concrete reality brought about by lexical customs and labels. While linking the labeled populations to concrete places and areas - Germany, Spain, Orient - toponymy could suggest a sort of writ of sedentary life. Though toponyms survived, history defeated territorial links. While setting them in motion, history swept up populations carrying them away from the places they had long been associated with. These collective entities that had been mistakenly considered as permanent residents bound to their place, owing to their labels, split into an infinite number of diasporic fragments. In keeping their original names though, each of these fragments in motion now had the duty to insure the future of rootless identities, to become the keeper of a language and of a culture, the depositary of the memory of a place, the witness of an absence. For a long time, Ashkenaz, Sefarad, Mizrah have hardly anything in common with Germany, Spain, and the Orient in their cartographic sense. These names refer to a geographic imaginary disconnected from geographical reality. However, if these labels are freely used with regard to maps and geography books, the spaces they call to mind draw another type of geography, a geography of time and memo-

8 As unsatisfying as it may appear, the choice of the term edot ha-mizrah intended to aggregate within one statistical category the Jews from Asia, Africa and Arab-Islamic countries, in other words populations supposedly little or not affected by modernity and western influences. Thereby, in applying it to its own co-religionists, the Israeli Administration (the Central Bureau of Statistics) was enforcing the wellaccepted Western orientalist approach brought from colonial expeditions. For a critical analysis of this issue, see Shohat 1999; 2001. On Orientalism, see Saïd. 
ry that makes sense with regard to genealogies, cultures, practices of transmission (languages, rituals, customs, gastronomy).

Moreover, Ashkenaz never claimed to be the name for Germany as such, nor for a broader German-speaking space. One can hardly imagine a German or Austrian native claiming to be an Ashkenaz. Ashkenaz was always a Jewish term, for a Jewish cultural space. A space within which Jews invented a particular way of life, developed a language anchored in local German vernaculars, also borrowing from Hebrew and Aramaic, from the Roman and Slavic languages spoken in the countries they wandered through. This was a space within which religious study and culture achieved great excellence thanks to the broad and deep knowledge of their spiritual masters and the quality of their Talmudic academies. Sefarad never claimed either to be the name for Spain nor for its inhabitants, even less for the Ottoman Empire or the Mediterranean coast. Like Ashkenaz, Sefarad designated only Jewish cultural spaces, within and between which Jews used to circulate and exchange goods and ideas among their communities and beyond. Here they developed their idiom of Judeo-Espanol, composed works in philosophy, mystics, poetry, excelled in the art of translation.

This particular way of living is proper to any diasporic group. As well as other sources of confusion springing from the decentering with regard to identity and origin, where, for instance, family names like Tedeschi (which means "German" in Italian) replaced the original Hebrew surname Ashkenazi, as a consequence of Ashkenazi family migrations to Italy. This type of otherness, through migrations and decenterings, is expressed by words, through the migration of names from one language to the other, as much as by deeds and gestures or ways of life.

The history of Jews in Diaspora was a succession of moves, a chronicle of migrations. The initial Founding Exile that marked the collective foundational narrative and memory as a veritable structural dimension of Judaism, was followed by many other expulsions and smaller exiles, more limited regarding their amplitude and effects but not less traumatic for those who experienced them. These alternations of migratory movements and periods of sedentary life reoccurring eventually blurred the very meaning of exile and Diaspora, shifting its focus and imaginary. Galut came to mean something different for the Ashkenazic Jews, different for the Sefardim. When the Inquisition expelled the Jews from Spain and Portugal, Sefardi Jews were forced into a new exile, the exile from Iberia. From then on, the elsewhere that dwelt in their collective memory and nostalgia in their new host countries were Spain and Portugal as much as the Jerusalem of the Psalmist. ${ }^{9}$ As Danielle Rozenberg writes (Rozenberg 2006, 27):

"It is the memory of the forced leaving, first, 'My ancestors were sorrow-stricken when they had to leave their Spanish dwelling, dreams of Spain ...' as the Judeo-Spanish romance says. From Morocco to Turkish Orient, the poets of exile chant the splendour of Sefarad and the regret for the lost homeland: 'Beloved Spain, we call you mother, and all our life-long the music of your language escorts us. Whereas you expelled us from your bosom, cruel mother, we still love you, holyland where our fathers buried their fathers and the ashes of thousands of beloved kins."”

9 See Psalm 137: "If I forget thee, O Jerusalem, ...". 
The same was true for Ashkenazic Jews in Germany, Poland or Russia, for the Jews expelled from England in 1290 by decree of Edward I, for Sefardic and Oriental Jews in North Africa, Egypt, Greece, Turkey or Iraq, for other uncategorized Jews dwelling in Ethiopia, Cochin or other lands. All had, at least once in their history, the experience of exile, the experience of being forced to leave the country where their ancestors had dwelled for centuries. Each time, exile affected only one limited segment of the entire Jewish world, but still it was kept in particular and collective memory. These fragments of memories "merged into the global religious and national memory of the original exile" (Rozenberg 2006, 51). These small-scale replicas of the original scenario contribute to the increase of the global Diaspora, the common fate of Jews in their dispersion, and at the same time they participate in its splitting into a multitude of fragments, each involving only a small part of the whole.

\section{The Reversal: The 'Diasporising' of the State of Israel}

Moreover, Diaspora Jews settling in Israel by choice accepted their relocation into a predominantly Jewish state, loosening or terminating former ties with places and people in their countries of origin. One may assume that some of them experienced the "return to Zion" with ambivalent feelings: as a positive achievement on the one hand, as a painful break, a sort of exile, on the other. This reversal of the original traditional spirit of exile may border on something seemingly scandalous in the perception of some. One should not minimize the fact that the places the newcomers left behind were often their birthplaces, the very places where they had grown up and spent much of their young formative years. In contrast with the immaterial and spiritualized promised land of religious memories and prayer books, these diasporic countries remain the concrete places of their origin, where their parents and forbears were born and buried. Although these places cannot pretend to compete as a "promised land," yet as time passes and distance grows they may rank among many other lost paradises in a kind of imagined community founded on exile. Their imprint in the mind helps keep the longing for return to these native places alive. If inaccessible for some reasons, it keeps nostalgia alive and becomes a major issue in family narratives transmitted from generation to generation.

Even more disconcerting is the fact that immigrants to Israel who had suffered stigmatization because they were labeled Jewish in the Diaspora, soon after their arrival in Israel have to endure being labeled "Russians," "Poles," "Moroccans," "Ethiopians" by their new Israeli compatriots. This seems paradoxical. In other words, indigenous and oldtimer Israelis seem to be in a hurry to identify the newcomers with a nationality which the immigrants were prepared to cast aside or jettison totally once in Israel, if by chance they had not already been denied it in their countries of origin (Khanin 2002). Beyond anecdote, what can we say about these exchanges of identity labels?

In demonstrating, sometimes harshly, their diversity of origins, Israeli Jews have reintroduced the reality of Diaspora, with its disparities and its cultural shocks, into the very center of Israel. Thus the whole country is being transformed into a concentrated mosaic of Jewish Diasporas within which anybody can feel free to claim their particularism and derive concrete or symbolic profits from it by means of societies or Landsmannschaften, lobbies, political or media channels. The modern State of Israel that was supposed to be the cure for the Jewish pathology represented by Diaspora, has become not only the heir to those realities reconstituted, but also the guardian and the caretaker of diasporic modalities of being Jewish that are now threatened and endangered in Diaspora. 
These distinctions and identifications based on national or geographic origins have effects: they reintroduce and update within Israel the logic of fragmentation that was proper to Diaspora. One additional aspect to be noticed is that this inner diasporization of Israel is no longer being carried out at the sole traditional conceptual and lexical levels - Ashkenaz, Sefarad, Mizrah - but also at the level of political modernity, including the use of categories borrowed from the universal lexicon (Russian, Pole, Moroccan, Ethiopian, French). This inner fragmentation based on countries of origin and nationalities comes in addition to the traditionally well-known diasporic categories. For if the practice of Russian, Polish, English or French languages replaced the use of Yiddish, Judeo-Spanish or Haketyiah ${ }^{10}$ most of the time among young generations or late newcomers, the legacy of the diasporic origin of modern Israel and of its early waves of immigrants did not disappear at all. It is still vibrant, especially through the use of immigrant languages, and has its place in collective representations and public institutions. For instance, the Ashkenaz versus Sefarad-Oriental (edot ha-mizrah) binary still remains the most commonly used indicator when analyzing the socio-economic and cultural divisions between wealthy and poor, bourgeois and workers, secular and religious, modern and traditional, etc. These divides have fissured Israeli society since its inception. The same binarism can be found at the pinnacle of the Central Rabbinate institution, where an Ashkenaz and a Sefarad Chief Rabbi share the title and the function of Chief Rabbis of Israel. The political sphere also reflects this bipolarization. It was already noted in sociological analysis: more liberal and left-liberal progressive secular parties are believed to attract a more Ashkenazic constituency, whereas nationalist right-wing parties tend to be attractive primarily to Sefaradic and/or oriental voters. This bipolarization is still present in political and ideological representations, even though the electoral map of Israel, like Israeli society at large, is much more complicated than before. In this respect, the creation of the Shass party in 1984 was a turning point for Israeli democracy and parliamentary life. For the first time, a party was created on an explicit Jewish ethnic anchoring rather than on a political or ideological one. The taboo that had prevailed for the sake of national unity of the "Jewish people" was jettisoned. For the first time, a Jewish political party claimed its ethnic character and was willing to support the cause of a specific Jewish ethnic group. ${ }^{11}$ The example was followed in subsequent years to such an extent that by now new divisions have been added to the pre-existent left/right and Jewish/Arab ones: intra-ethnic divisions opposing Ashkenazic Jews to Sefaradi Jews ${ }^{12}$ in keeping with the traditional diasporic lexicon, and the divisions according to countries of origin ${ }^{13}$ in conformity with the modern geopolitical lexicon (Khanin 2002).

10 A variant of Judeo-Spanish spoken in Morocco.

11 Shass was created by Sefardi religious leaders after their secession from the historically Ashkenaz religious party Agudat Isräl.

12 The Ashkenazi parties Agudat Yisraël and Degel ha-Torah (united within Yahadut ha-Torah) stand in opposition to the Sefardi party Shass.

13 Israël ba-Aliyah (N. Chtcharanski, 1995); Israël Betenu (Avigdor Liberman, 1999) which is a right-wing party of Russian immigrants; Lev Olim (1999) is a non-politically affiliated party of immigrants from Central Asia (former SU); Leader (1999) is a liberal democratic party of Russian immigrants; Atid Ehad ("One Future," 2005) is a party of the Ethiopian community. 


\section{Conclusion}

Alleging that Jews have had too much history and not enough geography is a meaningless assertion: from its inception, Jewish history has been a great lesson in the human geography of Diaspora, i.e. the map of the world.

Even though the Jewish condition has been de-dramatised, one should still be aware that all over the world men and women are permanently confronted with the violence of history. Nobody knows in advance what will come of it. Yet being a victim is not a fatality; history remains open and Diasporas retain the possibility of continuing their long-term history.

\section{Bibliography}

Anderson, B. (1991) Imagined communities. London, New York: Verso.

Azria, R. (1999) Identités juives et diaspora. Le paradigme diasporique à l'épreuve de la modernité. In: Miething, Christoph (ed.), Politik und Religion im Judentum. Romania Judaica, Tübingen: Max Niemeyer Verlag, 161-172.

Azria, R. (2002) Le Fait diasporique: une autre façon de penser l'Europe, une autre façon de penser le politique. In: Azria, R. (ed.), Croyances religieuses, morales et éthiques dans le processus de construction européenne. Commissariat général du Plan, Institut Universitaire de Florence, Chaire Jean Monnet d'Études Européennes, Paris: La Documentation française, 66-76.

Azria, R. (2004) Les juifs et l'héritage spirituel de l'Europe. In: Thiel, M.-J. (ed.), Europa, Religion und Kultur angesichts des Rassismus/Europe, spiritualité et culture face au racisme. München: Lit. Verlag (Forum Religion und Sozialkultur 11); Paris: Cerf, 207-216.

Baer, Y.F. (2000) Galout. L'imaginaire de l'exil dans le judaïsme. Paris: Calmann-Lévy (Trad. de l'allemand par Marc de Launay, préface de Yosef Hayim Yerushalmi, 1st edition Galut (1936), Berlin: Schocken Verlag).

Ben-Rafael, E.; Sharot, S. (1991) Ethnicity, Religion and Class in Israel. Cambridge: Cambridge University Press.

Ben-Rafael, E.; Gluckner, O.; Harris, P.; Israel, Y.; Jasper, W.; Luybansky, M.; Schoeps, J. (2006) The Making of a Diaspora. Russian Jews in Israel, Germany and the USA. Boston, Leyde: Brill.

Guez, O. (2007) L'impossible retour. Une histoire des juifs en Allemagne depuis 1945. Paris: Flammarion.

Khanin, V. (2002) The New Russian Jewish Diaspora and 'Russian' Party Politics in Israel. In: Nationalism \& Ethnic Politics 8(4): 46.

Khanin, V. (2005) The Vision of Return. Reflections on the Mass Immigration to Israel from the Former Soviet Union. In: Lesch, A.M.; Lustick, S. (eds.), Exile and Return. Predicaments of Palestinians and Jews. Pennsylvania: University of Pennsylvania Press, 183-203.

Lapierre, N. (1995) Changer de nom. Paris: Stock.

Rozenberg, D. (2006) L'Espagne contemporaine et la question juive. Les fils renoués de la mémoire et de l'histoire. Toulouse: Presses universitaires du Mirail.

Saïd, E. (1991) Orientalism. Vintage Books: Penguin.

Scholem, G. (1973) Sabbatai Sevi: The Mystical Messiah. Princeton, NJ: Princeton University Press. 
Shain, Y. (2007) Kinship and Diasporas in International Affairs. Michigan: University of Michigan Press.

Shohat, E. (1999) The Invention of the Mizrahim. In: Journal of Palestine Studies 29(1): $5-20$.

Shohat, E. (2001) Rupture and Return: A Mizrahi Perspective on the Zionist Discourse. http://web.mit.edu/cis/www/mitejmes/ (The MIT Electronic Journal of Middle East Studies, Crossing Boundaries: New Perspectives on the Middle East, Vol. 1).

Simon, M. (1948, 1983) Verus israel. Les relations entre Juifs et chrétiens sous l'empire romain (135-425). Paris: de Boccard.

Stora, B. (2006) Les trois exils. Juifs d'Algérie. Paris: Stock.

Régine Azria is researcher in sociology at the Centre National de la Recherche Scientifique (CNRS) and member of the Centre d'Etudes Interdisciplinaires des Faits Religieux (CEIFR), Ecole des Hautes Etudes en Sciences Sociales (EHESS).

Main research: Jewish identities, diaspora, and art.

E-mail: Regine.Azria@ehess.fr 